\title{
A Way Forward to Combat Insect Pest in Rice
}

\author{
M P Ali ${ }^{*}$, B Nessa'2, M T Khatun², M U Salam³ and M S Kabir
}

\begin{abstract}
The damage caused by insect pest is the continual factor for the reduction of rice production. To date, 232 rice insect pest species are identified in Bangladesh and more than 100 species of insects are considered pests in rice production systems globally, but only about 20 - 33 species can cause significant economic loss. The major goal of this study is to explore all the possible ways of developed and proposed technologies for rice insect pests management and minimize economic losses. Insect pests cause $20 \%$ average yield loss in Asia where more than $90 \%$ of the world's rice is produced. In Bangladesh, outbreak of several insects such as rice hispa, leafroller, gallmidge, stem borers and brown planthopper $(\mathrm{BPH})$ occurs as severe forms. Based on previous reports, yield loss can reach upto $62 \%$ in an outbreak situation due to hispa infestation. However, BPH can cause $44 \%$ yield loss in severe infestested field. To overcome the outbreaks in odd years and to keep the loss upto 5\%, it is necessary to take some preventive measures such as planting of resistant or tolerant variety, stop insecticide spraying at early establishment of rice, establish early warning and forecasting system, avoid cultivation of susceptible variety and following crop rotation. Subsequent quick management options such as insecticidal treatment for specific insect pest should also be broadcasted through variety of information systems. Advanced genomic tool can be used to develop genetically modified insect and plants for sustainable pest management. In addition, to stipulate farmers not use insecticides at early crop stgae and minimize general annualized loss, some interventions including training rice farmers, regular field monitoring, digitalization in correct insect pests identification and their management (example; BRRI rice doctor mobile app), and demonstration in farmers field. Each technology itself solely or combination of two or more or all the packages can combat the insect pests, save natural enemies, harvest expected yield and contribute to safe food production in Bangladesh.
\end{abstract}

Key words: Insect pests, rice, management, safe food, increase productivity

\section{INTRODUCTION}

Insect pest is a major constraint to rice production. Rice plants are vulnerable to insect feeding at the time of sowing till harvesting. Both the mature and immature stages of insects can injure rice plants by chewing leaf and root tissues, boring and tunneling into stems, or sucking fluid sap from stems and grains. However, insect pest attacks frequently occur with varying intensities and frequencies possibly induced by the changes in climate and cropping systems in modern rice cultivation. Two hundred sixty-seven insect pest species, 185 parasitoids, and 192 predators are known to occur in Bangladesh rice ecosystems (Islam and Catling, 2012; Islam et al., 2003; Ali et al., 2017). However, 20 - 33 species are considered significant pests capable of causing yield losses if they infest plants in sufficiently large numbers (Table 1). The insect attacking rice can be divided into major and minor pests. The major pest is those which frequently cause very distinct economic damage and minor pests are those insects which are often found but cause less serious damage (Halteren, 1979). To control insect pests, insecticides are applied 2-4 times each season in rice fields (Haque, 2014), resulting in 6-12 pesticide applications per year. Agricultural production practices used 39,464 tons of pesticides in 2014 (BPCA, 2015), with over $80 \%$ used in rice fields to combat pests and diseases (BBS, 2015). Thus insect pest sometimes causes the barrier to sufficient food production in Bangladesh. Kabir et al. (2015) outline different smart technology such as location-specific variety, profitable cropping sequences, innovative cultural management, and mechanization coupled with smart dissemination approaches to overcome this barrier.

1Entomology Division, Bangladesh Rice Research Institute (BRRI), Gazipur-1701, Bangladesh; 2Plant Pathology Division, BRRI, Gazipur-1701, Bangladesh; ${ }^{3}$ Freelance International Consultant (Agricultural Systems), Bangladesh; ${ }^{4}$ Director General, BRRI, Gazipur-1701, Bangladesh.

*Corresponding author's E-mail: panna_ali@yahoo.com (M P Ali) 
Predators and parasitoids often attack these pests and control them naturally in the field. Over the last three decades, the introduction of high-yielding rice varieties to feed the fast-growing human population in developing countries, such as Bangladesh, has resulted in the use of large quantity of chemical insecticides. This heavy reliance on chemical insecticides reduces natural enemy populations in rice landscapes, promoting pest outbreaks (Heong et al., 2015). Intensive rice production with the primary goal of achieving high yield is often characterized by the excessive application of fertilizers and pesticides.

It has led to many negative environmental effects, such as the reduction of biodiversity and natural biological control, high pesticide residues in rivers, drinking water, and agricultural products, rapid and high insecticide resistance in pests, secondary pest outbreaks, environmental pollution, and ecological imbalance. These severe negative effects will damage the ecosystem, lead to frequent pest outbreaks, and in turn require an increased pesticide dosage, which forms a vicious circle (Conway and Pretty, 1991). Excessive and irrational use of pesticides has become a major obstacle to sustainable agriculture in Bangladesh and is also threatening food safety and human health.

Recently, new principles, technologies, and strategies of pest management have been developed. One of the principle is 'green plant protection', which has been widely accepted (Lu et al., 2012; Ye, 2013). Ecological control practice is another set of strategies introduced to reduce insecticide use, and one of the strategies is ecological engineering (Ali et al., 2019; Gurr et al., 2016). With the above background, this article undertook three specific objectives in relation to rice insect pests in Bangladesh: (i) scenario of their changing status, (ii) highlighting the scenarios of yield loss associated with the insect pests, and (iii) development and mapping the action plan for three decades on reducing yield loss from the insect pests.

\section{METHODOLOGY}

First, we explored the rice yield loss due to insect pests in Bangladesh. Several literatures were taken in mind and finally set up a national yield loss of rice production in Bangladesh (Tables 2 and 3). All data and several ideas were collected from secondary sources. A simple diagram has been proposed to make network between farmer's field problems and researchers through GIS. The idea for the model/diagram was adopted from different reports, has been modified by the authors. The baseline data for yield loss has set after a thoroughly discussion by a group of rice scientists worked in doubling rice productivity by 2030, on 11 November 2019. Except abnormal year (when pest outbreak occurs frequently), we assumed and fixed that the insect pest causes $1.0 \%$ national average yield loss of rice every year. However, the literature on rice yield losses due to insect pests in Bangladesh are different due to yield loss assessment methods. The reported findings were obtained from experimental plots comparing to control one where insect pest management practices were not allowed or a survey report obtained from a pest outbreak field. This is not happened in total production areas of the country in any year. Therefore, we can not calculate the total national loss based on this report. Typically, insect pests cause $18 \%$ yield loss to rice production in experimental plots when compared to the control plot (no actions were undertaken) in Bangladesh. Currently, control of these arthropod pests solely depends on chemical pesticides (Islam et al., 2003). During 2011 and 2012, about 20-24 thousand tons formulated (as an active ingredient, a total of 1900-2400 tons) insecticide was used in Bangladesh (BCPA, 2013) with more than half of that amount applied against rice insect pests. Therefore, alternatives control approaches and forthcoming novel concepts were explored and described here. Based on this study, several recommendations were made for current and future studies. 
RESULTS AND DISCUSSION

\section{Status of rice insect pests in Bangladesh}

Table 1 presents the pest order and their status

to date. These insect pests cause losses in rice production. Insect pests attack all portions of the rice plant and all stages of plant growth. Feeding guilds consist of (1) root feeders, (2) stem borers, (3) leafhoppers and planthoppers, (4) defoliators, (5) grain suckers, and (6) ear cutting insects. Insects also attack rice grains in storage.

Table 1. List of major ${ }^{*}$ rice insect pest and changes their status in Bangladesh from 1965 to 2019.

\begin{tabular}{|c|c|c|c|}
\hline $\begin{array}{l}1965 \\
\text { (Alam 1965) }\end{array}$ & $\begin{array}{l}1977 \\
\text { (BRRI literature review) }\end{array}$ & $\begin{array}{l}2009 \\
\text { (Islam et al., 2009) }\end{array}$ & $\begin{array}{l}2020 \\
\text { (Based on outbreak observation) }\end{array}$ \\
\hline Major pests ${ }^{1}$ & Major pests & Major pests & Major pests \\
\hline $\begin{array}{l}\text { 1. Rice ear-cutting } \\
\text { caterpillar }\end{array}$ & $\begin{array}{l}\text { 1. Rice stem } \\
\text { borers (YSB, DHB, PB) }\end{array}$ & 1. Stem borers & $\begin{array}{l}\text { 1. Brown } \\
\text { Planthopper }\end{array}$ \\
\hline $\begin{array}{l}\text { 2. Rice swarming } \\
\text { caterpillar }\end{array}$ & $\begin{array}{l}\text { 2. Green } \\
\text { leafhoppers }\end{array}$ & $\begin{array}{l}\text { 2. Brown } \\
\text { planthopper } \\
\text { White backed } \\
\text { Planthopper }\end{array}$ & 2. Stem borers \\
\hline $\begin{array}{l}\text { 3. Rice stem borers } \\
\text { (YSB, DHB, PB) }\end{array}$ & $\begin{array}{l}\text { 3. Rice ear-cutting } \\
\text { caterpillar }\end{array}$ & 3. Rice hispa & $\begin{array}{l}\text { 3. Rice } \\
\text { leaffolder }\end{array}$ \\
\hline 4. Rice hispa & 4. Rice gall midge & $\begin{array}{l}\text { 4. Rice gall } \\
\text { midge }\end{array}$ & 4. Rats \\
\hline 5. Rice bug & 5. Rice hispa & 5. Rice bug & 5. Green leafhopper \\
\hline 6. Green leafhoppers & 6. Rice bug & 6. Rice leaffolder & 6. Rice hispa \\
\hline 7. Rice caseworm & 7. Rice leaffolder & 7. Green laefhoppers & 7. Rice gall midge \\
\hline 8. Rice mealybug & $\begin{array}{l}\text { 8. Rice swarming } \\
\text { caterpillar }\end{array}$ & & 8. Rice bug \\
\hline 9. Rice grasshoppers ${ }^{2}$ & 9. Rice caseworm & & 9. White backed planthopper \\
\hline 10. Field cricket & 10. Rice mealy bug & & \\
\hline 11. Rats & 11. Rice whorl maggot & & \\
\hline Minor pests & Minor pests & Minor pests & Minor pests \\
\hline $\begin{array}{l}\text { 1. Whitebacked } \\
\text { planthopper }\end{array}$ & 1. Rice grasshoppers ${ }^{2,3}$ & 1. Ear-cutting caterpillar & 1. Whorl maggot \\
\hline 2. Rice grasshoppers ${ }^{3}$ & 2. Rice thrips & 2. Swarming caterpillar & 2. Ear-cutting caterpillar \\
\hline 3. Rice gall midge & $\begin{array}{l}\text { 3. Orange-headed } \\
\text { leafhopper }\end{array}$ & 3. Mealy bug & 3. Rice thrips \\
\hline $\begin{array}{l}\text { 4. Rice leaf roller } \\
\text { (leaffolder) }\end{array}$ & 4. Field cricket & 4. Whorl maggot & 4. Caseworm \\
\hline $\begin{array}{l}\text { 5. Rice hairy } \\
\text { caterpillar }\end{array}$ & 5. Rice leaf beetle & 5. Caseworm & $\begin{array}{l}\text { 5. Small brown } \\
\text { planthopper }\end{array}$ \\
\hline 6. Rice leaf beetle ${ }^{4}$ & 6. Brown planthopper & $\begin{array}{l}\text { 6. Field cricket, Long-horned } \\
\text { cricket }\end{array}$ & 6. Rice grasshoppers ${ }^{3}$ \\
\hline 7. Rice thrips & 7. Rice hairy caterpillar & 7. Rice thrips & 7. Rice skipper \\
\hline 8. Rice skipper & 8. Rice leaf butterfly & & 8. Rice mealybug \\
\hline 9. Rice leaf butterfly & 9. Rice skipper & & $\begin{array}{l}\text { 9. Long-horned cricket } \\
\text { 10. Field cricket } \\
\text { 11. Mole cricket }\end{array}$ \\
\hline
\end{tabular}

${ }^{1}$ Number associated with each pest represents the rank of pest status in the respective reported year; ${ }^{2}$ Hieroglypbus baniar; ${ }^{3}$ Oxya spp; ${ }^{4}$ Leptispa pygmaea; YSB-yellow stem borer, DHB-dark-headed borer, PB-pink borer."The major pests are those which frequently cause a very distinct economic damage and minor pests are those insects which are often found but cause less serious damage (Halteren, 1979). 
At the last count in 2003, 644 arthropod species have been observed in Bangladesh: 267 phytophagous insects, 192 predators, and 185 parasitoids (Islam and Catling, 2012; Islam et al., 2003). However, we can see that there have been several assessments and that the pest status has shifted significantly over the last 60-70 years. Hazarika (1952) reported six rice pests: the yellow stem borer was the top of the list, followed by rice swarming caterpillar, rice hispa, rice bug, rice earcutting caterpillar, and the rice caseworm. Alam (1965) reported 20 significant pests of which 11 are considered as major pests. The major pests are those which frequently cause very distinct economic damage and minor pests are those insects which are often found but cause less serious damage (Halteren, 1979).

\section{Root feeders}

Figure 1 shows the beetle and its damaged symptom. Examples of root feeders are scarabaeid beetles, and the rice water weevil, Lissorhoptrusoryzophilus (order Coleoptera). Black beetle feeds on the roots and severely reduces the root system. The adult water weevil feeds on the leaves and causes little damage while the larvae feed on the roots and severely reduce the root system.

Plants with reduced root systems grow poorly and have low yields. The scarabaeid beetles Heteronychus lioderes burrow into the base of the rice plant. Peak activity period is at night. They burrow underground and damage many plants, causing patches of dead plants in the fields. Beetles also damage irrigated crops in flooded fields. Beetles lay eggs a few days after emergence. About one month later grubs begin to cause damage. They feed on roots, rootlets, and root hairs. They also make damage plant by chewing the base of the stem just above the roots. Attacked plants can easily be pulled from the soil.
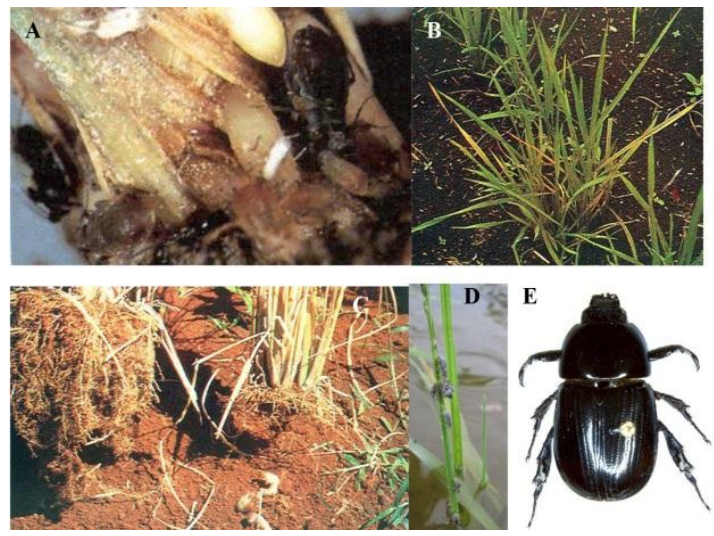

Fig. 1. Rice root feeder and its damaged symptom observed in rice field. A. Wingless adult (root aphid) feeding on root. B. Visible field damaged caused by root aphid; C. Uprooted rice plant with root feeding damage by white grub; D. Water weevil (adult) on rice plant; E. Rice black beetle (Scarabaeid beetle). Image taken from IRRI Knowledge bank.

\section{Stem borers}

Figure 2 demonstrates the yellow stem borer and its damaged symptoms. Stem borers consist primarily of insects in the lepidopterous families, Noctuidae and Pyralidae. Three species of rice stem borers including yellow stem borer (Scirpophaga incertulas), dark-headed stem borer (Chilo polychrysa), pink stem borer (Sesamia inferens) are commonly found in Bangladesh. Among them, yellow stem borer is the most dominant species in Bangladesh.

The adult moths lay eggs on rice leaves and the larvae bore into the stem. Feeding in the stem during the vegetative growth stage of the plant (seedling to stem elongation) causes death of the central shoot ("deadheart"). Damaged shoots do not produce a panicle, and thus, produce no grain. Feeding of stem borers during the reproductive stage (panicle initiation to milk grain) causes a severing of the developing panicle at its base. As a result, the panicle is unfilled and whitish in color, rather than filled with grain and brownish in color. Such empty panicles are called "whiteheads". 


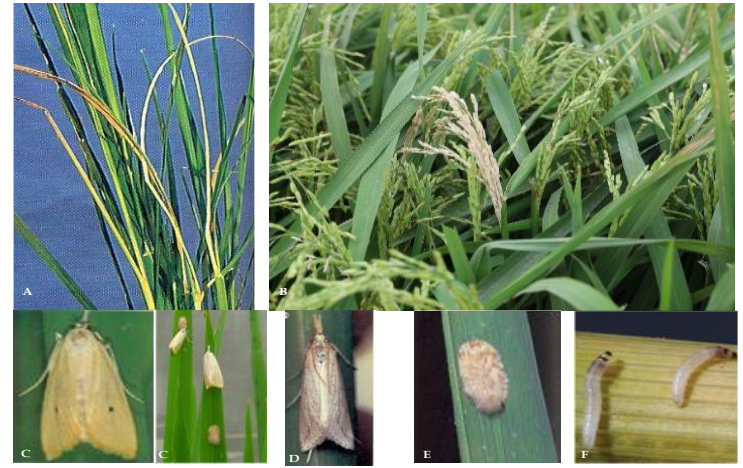

Fig. 2. Yellow stem borer and its damaged symptoms observed in the field. A. Deadheart observed at the vegetative stage; $B$. Whitehead observed at the reproductive stage; $C$. Female adult moth; D. Male adult moth; Egg mass observed in rice leaf; F. Larvae of stem borer. Some photos taken from IRRI and BRRI rice knowledge bank.

\section{Leafhoppers and planthoppers}

In general, the leafhoppers (family Cicadellidae) attack all aerial parts of the plant whereas the planthoppers (family Delphacidae) attack the basal portions (stems). The leafhoppers and planthoppers (order Hemiptera) are sucking insects which remove plant sap from the xylem and phloem tissues of the plant. Severely damaged plants dry and take on the brownish appearance of plants that have been damaged by fire. Hence, hopper damage is called "hopper burn" (Fig. 3). The relative importance of leaf and planthopper pests varies from country to country, although the planthoppers - brown planthopper (BPH), Nilparvata lugens; the whitebacked planthopper (WBPH), Sogatella furcifera; small brown planthopper (SBPH), Laodelphax striatellus, and green leafhopper, Nephotettix virescens-affect most rice-growing areas in Bangladesh. These insects are severe pests in Bangladesh as well in Asia where they not only cause direct damage, by removing plant sap, but are also vectors of serious rice virus diseases, such as rice tungro virus transmitted by the green leafhopper, Nephotettix virescens, and grassy stunt virus transmitted by the brown planthopper, Nilaparvata lugens.
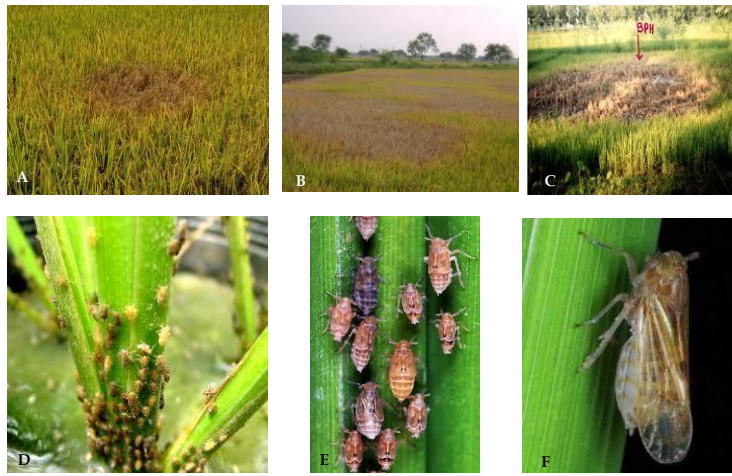

Fig. 3. Brown planthopper and its damaged symptoms observed in the rice field. A-C. Hopper burn observed in rice field; D. Nymphs settled on the base of the plant and sucking the sap; E. Fifth instar nymphs; F. Adult brown planthopper. Photo source: IRRI rice knowledge bank.

\section{Defoliators}

A large group of insects belonging to several insect orders feeds on rice leaves. Most common are the larvae and adults of beetles (order: Coleoptera), larvae of the order Lepidoptera and grasshoppers (order: Orthoptera). Defoliation reduces the photosynthetic capacity of the rice plant and thereby decreases yields. However, when feeding damage occurs early in rice growth, plants have the ability to compensate for damage by producing new tillers. Thus, rice plants in the actively tillering stage of growth can tolerate a certain level of leaf damage without any yield loss. Among the leaf feeders, rice leaf roller (RRL), Cnaphalocrocis medinalis becomes dominant and observed all over the country. The RLR causes longitudinal and transparent whitish streaks on damaged leaves and tubular folded leaves (Fig. 4). It often attacks rice in the early crop stages, causing highly visible leaf injury, but, because of plant compensation, the injury often does not translate into a yield loss (Graf et al., 1992). There are at least three species of armyworm which attack rice in Asia. These are the rice swarming caterpillar, common cutworm, and the rice ear-cutting caterpillar. 

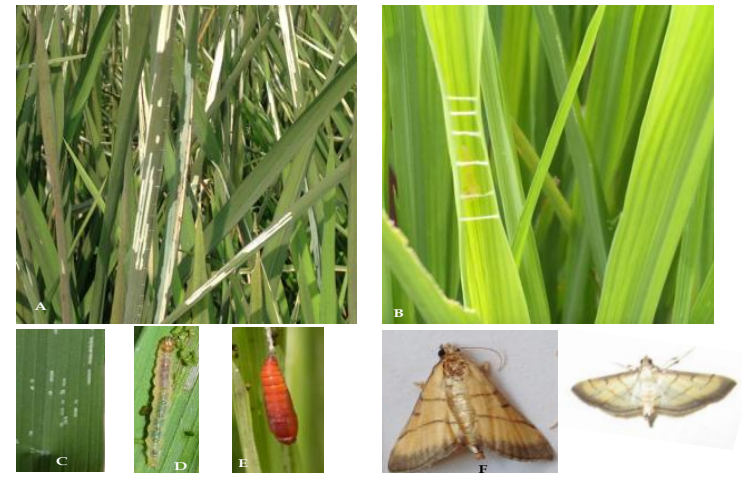

Fig. 4. Rice leaf roller and its damage observed in the field. A. Damaged leaves caused by leaf roller larvae; B. Rolled leaf with threads; C. Egg laid by adult moth found in leaf; D. Leaf roller larva; E. Pupa; F. Adult moth. Images C-E were taken from www.crida.in.

\section{Grain sucking insects}

The rice bug, known for the foul odor produced by the scent glands on their abdomen, penetrates the developing grain with their sucking mouthparts and remove the white fluid referred to as "milk". Damage early in the development of the grain prevents the filling of the grain. Later attack results in "pecky rice" which is referred to as the condition of the grain after being sucked by rice bugs and the grain being subsequently stained by the bacteria or fungi which enter the puncture wounds. In some countries, the market price of pecky rice is reduced.

\section{Ear cutter}

The insect cuts the base of the panicles and those are left simply bend over of fall. Grassgreen young larvae with dorsal stripes appear on the plants. Damage is often localized at the same time as the larvae migrate in the group between them. Ear-cutting caterpillar is commonly called armyworms that attack rice. There are at least three species of armyworm which attack rice in Asia. However, only the rice ear-cutting caterpillar, Mythimna separata is a moth of the family Noctuidae cut the panicle at the ripening stage of rice.

\section{Scenarios of yield loss from rice insect pests}

The average yield loss due to various insect pests in Asia where more than $90 \%$ of the world's rice is produced about 20\% (Pathak and Khan, 1994). Any decrease in pest damage means a corresponding increase in needed rice production. A series of crop-loss assessment trials were carried out in the field by the Entomology Division of the BRRI against major insect pests from 1977 to 1979 have shown an average yield loss of $13 \%$ in the boro season, $24 \%$ in the Aus season, and $18 \%$ in the transplanted Aman (T. Aman) season (Alam et al., 1981). However, the amount of loss caused by insect pests varied to the estimated year and method (Table 2).

\section{Potential yield loss}

Yield loss can be greatly varied to insect pest species, rice variety, and geographic location. Table 2 shows yield loss due to insect pests estimated against different rice insect pests. Brown planthopper (BPH) can cause the highest yield loss in an outbreak area. The severity of the pest outbreak depends on the year. In an outbreak situation, insects like brown planthopper and rice hispa can increase loss by $44 \%$ and $62 \%$ respectively (Table 3 ).

Table 2. Annual national rice yield loss scenario due to insect pests in Bangladesh.

\begin{tabular}{lllll}
\hline Loss (\%) & Mode of estimation & Year of reporting & Reference & Comments \\
\hline 06.00 & Insecticidal check method & 1951 & Alam, 1961 & Field test \\
08.67 & Insecticidal check method & 1976 & Catling et al., 1978 & - \\
18.00 & Crop loss assessment 1977-1979 & 1980 & Alam et al., 1981 & - \\
08.10 & Survey estimation & 1999 & Islam and Catling, 2012 & - \\
$04-14$ & Literature review & 2010 & Mondal, 2010 & - \\
01.00 & Expert opinion on total production & 2020 & Kabir et al., 2020 & Average annual national \\
& & & & loss \\
\hline
\end{tabular}


Table 3. Yield loss estimation from research data under various experimental situations in Bangladesh.

\begin{tabular}{lllll}
\hline Insect pest & Loss $(\%)$ & Year of reporting & Reference & Comments \\
\hline Brown planthopper $(\mathrm{BPH})$ & $20-44$ & 1985 & BRRI, 1985b & Depends on season \\
Rice hispa & $11-62$ & 1985 & BRRI, 1985a & Depends on season \\
Rice hispa & $8.5-32.85$ & 2012 & Bari et al., 2012 & Depends on season and variety \\
Stem borer & 15.0 & 1985 & BRRI, 1985b & \\
Major insects & $22-26$ & 1985 & BRRI, 1985a & Depends on season \\
Rice hispa & $20-39$ & $1982-1986$ & Karim, 1989 & Depends on season \\
Leaf roller & $4-11$ & $1982-1986$ & Karim, 1989 & - \\
Mealy bug & $9-22$ & $1982-1986$ & Karim, 1989 & - \\
Ear-cutting caterpillar & 9.0 & $1982-1986$ & Karim, 1989 & - \\
\hline
\end{tabular}

\section{Annualized national yield loss status}

Climate change aggravates the outbreak of several insect pests including brown planthopper, leafroller, stem borer, and white backed planthopper. These insect pests cause significant economic loss. We assumedand fixed a generalized annual average loss $1.0 \%$ of total national rice production in Bangladesh (Kabir et al., 2020). However, differential reports on losses can found in the literature (Tables 2 and 3). Research results suggested that insect pests can cause $6-18 \%$ loss in Bangladesh. Based on the survey, this loss can be $4-8.1 \%$ in a normal year where pest outbreaks almost absent. However, the loss can be reached upto $44-62 \%$ in an odd year (when pest outbreak occurs frequently). Figure 5 depicts the rice yield losses incurred by insect pests in two different scenarios (survey and research reports).Therefore, we target to minimize this loss from $62 \%$ to $5 \%$ (Fig. 5) by implementing preventive methods such as stop insecticide application at the early establishment of rice, add flowering strips in the rice landscape, establish an early warning and forecasting system, use of balanced fertilizer, avoid cultivation of susceptible variety, growing resistant or tolerant varieties and follow crop rotation. Subsequent quick management options such as insecticidal treatment for specific insect pests should also be broadcasted through TV channels, and newspapers to check the abnormal situations in an odd year. Major efforts proposed above to minimize the economic loss in an odd year when pest outbreaks occur frequently and keep the loss upto $5 \%$. These could be achieved by implementing proposed management technologies (summarized in Table 6).

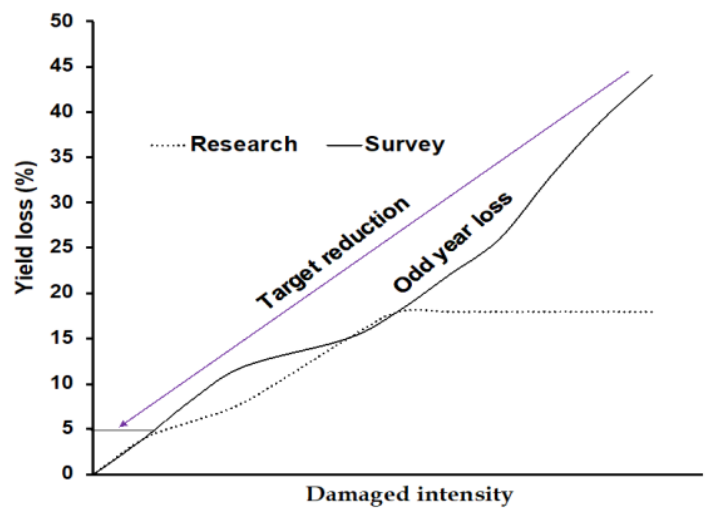

Fig. 5. Trends of rice yield losses in different scenarios. Losses incurred by insect pest estimated by researches, and surveys (outbreaks year). Blueline indicates the minimizing amount of loss by targeting different management technologies.

Action plan for three decades on reducing yield loss from rice insect pests

Tables $4 \mathrm{a}, 4 \mathrm{~b}$ and $4 \mathrm{c}$ show the action plans to reduce the real yield loss in rice and prevent the abnormal outbreak of insect pests in the rice field. Elaboration of different strategic terms used in Tables $4 \mathrm{a}, 4 \mathrm{~b}$ and $4 \mathrm{c}$ is enlisted in Table 5. According to action plans enlisted in these Tables, we briefly described the important core insect pest management approaches. The following approaches will be implemented sequentially during the next three decades from 2021-2050. 
Table 4a. Action plant for location, variety, and insect pest specific smart management for a period for 2021-2030. Elaboration of each term used in this Table is listed in Table 5.

\begin{tabular}{|c|c|c|c|c|c|c|c|c|c|c|}
\hline \multirow{5}{*}{ Insect pest } & \multicolumn{10}{|c|}{ Location, variety and insect pest specific smart management } \\
\hline & \multicolumn{10}{|c|}{ Period: $2021-2030$} \\
\hline & \multicolumn{7}{|c|}{ Research and development phase } & \multicolumn{3}{|c|}{ Dissemination phase } \\
\hline & \multicolumn{2}{|c|}{ Primary } & \multicolumn{2}{|c|}{ Intermediate } & \multicolumn{2}{|l|}{ Maturation } & \multirow{2}{*}{\begin{tabular}{|l} 
Follow up \\
$\mathrm{CM}$
\end{tabular}} & \multirow{2}{*}{\begin{tabular}{|l|} 
Step-1 \\
Train
\end{tabular}} & \multirow{2}{*}{$\begin{array}{l}\text { Step-2 } \\
\text { Demo }\end{array}$} & \multirow{2}{*}{\begin{tabular}{|l|} 
Step-3 \\
EW
\end{tabular}} \\
\hline & IBR & YL-EST & Mtg-FWK & EPI & Cali-Valid & Sm-Mtg & & & & \\
\hline \multicolumn{11}{|l|}{ Brown planthopper } \\
\hline \multicolumn{11}{|l|}{ Stem borer } \\
\hline \multicolumn{11}{|l|}{ Leaffolder } \\
\hline \multicolumn{11}{|l|}{ Green leafhopper } \\
\hline \multicolumn{11}{|l|}{ Gallmidge } \\
\hline \multicolumn{11}{|l|}{ Rice hispa } \\
\hline \multicolumn{11}{|l|}{ White backed planthopper } \\
\hline \multicolumn{11}{|l|}{ Rice bug } \\
\hline \multicolumn{11}{|l|}{ Thrips } \\
\hline \multicolumn{11}{|l|}{ Caseworm } \\
\hline \multicolumn{11}{|l|}{ Ear-cutting caterpillar } \\
\hline \multicolumn{11}{|l|}{ Rice mealy bug } \\
\hline \multicolumn{11}{|l|}{ Rice whorl maggot } \\
\hline \multicolumn{11}{|l|}{ Rats } \\
\hline Any other emerging insect pest & & & & & & & & & & \\
\hline
\end{tabular}

Table 4b. Action plant for location, variety, and insect pest specific smart management for a period for 2031-2040. Elaboration of each term used in this Table is listed in Table 5.

\begin{tabular}{|c|c|c|c|c|c|c|c|c|c|c|}
\hline \multirow{4}{*}{ Insect pest } & \multicolumn{10}{|c|}{$\begin{array}{l}\text { Location, variety and insect pest specific smart management } \\
\text { Period: } 2031-2040\end{array}$} \\
\hline & \multicolumn{7}{|c|}{ Research and development phase } & \multicolumn{3}{|c|}{ Dissemination phase } \\
\hline & \multicolumn{2}{|c|}{ Primary } & \multicolumn{2}{|c|}{ Intermediate } & \multicolumn{2}{|l|}{ Maturation } & \multirow{2}{*}{$\begin{array}{l}\text { Follow up } \\
\mathrm{CM}\end{array}$} & \multirow{2}{*}{\begin{tabular}{|l|} 
Step-1 \\
Train \\
\end{tabular}} & \multirow{2}{*}{$\frac{\text { Step-2 }}{\text { Demo }}$} & \multirow{2}{*}{\begin{tabular}{|l|} 
Step-3 \\
EW
\end{tabular}} \\
\hline & IBR & YL-EST & Mtg-FWK & EPI & Cali-Valid & Sm-Mtg & & & & \\
\hline \multicolumn{11}{|l|}{ Brown planthopper } \\
\hline \multicolumn{11}{|l|}{ Stem borer } \\
\hline \multicolumn{11}{|l|}{ Leaffolder } \\
\hline \multicolumn{11}{|l|}{ Green leafhopper } \\
\hline \multicolumn{11}{|l|}{ Gallmidge } \\
\hline \multicolumn{11}{|l|}{ Rice hispa } \\
\hline \multicolumn{11}{|l|}{ White backed planthopper } \\
\hline \multicolumn{11}{|l|}{ Rice bug } \\
\hline \multicolumn{11}{|l|}{ Thrips } \\
\hline \multicolumn{11}{|l|}{ Caseworm } \\
\hline \multicolumn{11}{|l|}{ Ear-cutting caterpillar } \\
\hline \multicolumn{11}{|l|}{ Rice mealy bug } \\
\hline \multicolumn{11}{|l|}{ Rice whorl maggot } \\
\hline \multicolumn{11}{|l|}{ Rats } \\
\hline Any other emerging insect pest & & & & & & & & & & \\
\hline
\end{tabular}


Table 4c. Action plant for location, variety, and insect pest specific smart management for a period for 2041-2050. Elaboration of each term used in this Table is listed in Table 5.

\begin{tabular}{|c|c|c|c|c|c|c|c|c|c|c|}
\hline \multirow{4}{*}{ Insect Pest } & \multicolumn{10}{|c|}{ Location, variety and insect pest specific smart management } \\
\hline & \multicolumn{7}{|c|}{ Research and development phase } & \multicolumn{3}{|c|}{ Dissemination phase } \\
\hline & \multicolumn{2}{|c|}{ Primary } & \multicolumn{2}{|c|}{ Intermediate } & \multicolumn{2}{|c|}{ Maturation } & \multirow{2}{*}{$\begin{array}{l}\text { Follow } \\
\text { up }\end{array}$} & \multirow{2}{*}{$\begin{array}{l}\begin{array}{l}\text { Step- } \\
1\end{array} \\
\text { Train }\end{array}$} & \multirow{2}{*}{$\begin{array}{l}\text { Step- } \\
2 \\
\text { Dem } \\
0\end{array}$} & \multirow{2}{*}{$\begin{array}{l}\text { Step- } \\
3 \\
\text { EW }\end{array}$} \\
\hline & $\begin{array}{l}\mathrm{IB} \\
\mathrm{R}\end{array}$ & $\begin{array}{l}\text { YL- } \\
\text { EST }\end{array}$ & $\begin{array}{l}\text { Mtg- } \\
\text { FWK }\end{array}$ & $\begin{array}{l}\text { EP } \\
\text { I }\end{array}$ & $\begin{array}{l}\text { Cali- } \\
\text { Valid }\end{array}$ & $\begin{array}{l}\text { Sm- } \\
\text { Mtg }\end{array}$ & & & & \\
\hline Brown planthopper & & & & & & & & & & \\
\hline Stem borer & & & & & & & & & & \\
\hline Leaffolder & & & & & & & & & & \\
\hline Green leafhopper & & & & & & & & & & \\
\hline Gallmidge & & & & & & & & & & \\
\hline Rice hispa & & & & & & & & & & \\
\hline White backed planthopper & & & & & & & & & & \\
\hline Rice bug & & & & & & & & & & \\
\hline Thrips & & & & & & & & & & \\
\hline Caseworm & & & & & & & & & & \\
\hline Ear-cutting caterpillar & & & & & & & & & & \\
\hline Rice mealy bug & & & & & & & & & & \\
\hline Rice whorl maggot & & & & & & & & & & \\
\hline Rats & & & & & & & & & & \\
\hline $\begin{array}{l}\text { Any other emerging insect } \\
\text { pest }\end{array}$ & & & & & & & & & & \\
\hline
\end{tabular}

Table 5. Elaboration of different strategic terms used in Table $4 a, 4 b$ and $4 c$.

\begin{tabular}{|c|c|c|c|}
\hline Programme & Phase & Stage & Action \\
\hline \multirow[t]{7}{*}{$\begin{array}{l}\text { Research and } \\
\text { Development }\end{array}$} & \multirow[t]{2}{*}{ Primary } & $\mathrm{IBR}^{*}$ & $\begin{array}{l}\circ \text { Identification (symptom \& the insect pest) } \\
\circ \text { Biology (for genetic ID \& reproductive behavior) } \\
\circ \text { Rearing (mass rearing technique) }\end{array}$ \\
\hline & & YL-EST & ○ Yield loss estimation (by insect pest severity scale) \\
\hline & \multirow[t]{2}{*}{ Intermediat } & $\begin{array}{l}\text { Mtg- } \\
\text { FWK }\end{array}$ & $\begin{array}{l}\text { Managementframework (considering all possible options, based on } \\
\text { current knowledge) }\end{array}$ \\
\hline & & $\mathrm{EPI}^{*}$ & $\begin{array}{l}\text { Epidemiology (based on local conditions, not just on information from the } \\
\text { literature. Finding the exact driver(s) of the insect pest epidemics }\end{array}$ \\
\hline & \multirow[t]{2}{*}{ Maturation } & $\begin{array}{l}\text { Cali- } \\
\text { Valid }\end{array}$ & $\begin{array}{l}\circ \text { Calibration and Validation (testing every component of the management } \\
\text { framework by location \& variety; applying all tools) }\end{array}$ \\
\hline & & SmMtg & ○ Smart management package developed to be acceptable to farm adoption \\
\hline & Follow up & CM & $\begin{array}{l}\text { Continuous monitoring to keep on notice if changes happening on smart } \\
\text { management package, e.g., variety tolerance; reaction to new varieties }\end{array}$ \\
\hline \multirow[t]{3}{*}{ Dissemination } & Phase-1 & Train & o Training (DAE officers and lead farmers) \\
\hline & Phase-2 & Demo & o Demonstration (in the location of insect pest risk) \\
\hline & Phase-3 & EW & ○ Early warning system-based insect pest alert communicated to farmers \\
\hline
\end{tabular}

"IBR: Identification, Biology and Rearing; EPI: Epidemiology; Cali-Valid: Calibration and Validation; CM: Continuous monitoring; SmMtg: Smart management; Train: Training; YL-EST: Yield loss estimation; Demo: Demonstration; EW: Early warning; DAE: Department of Agricultural Extension 
Approaches to be followed to address insect pest management

\section{Stop spraying at early growth stage of rice}

Currently, insect pest management solely depends on chemical insecticide which has a tremendous impact on the environment, animal, and human health. Farmers usually apply insecticides 2-4 times in a season in their rice fields. Most of the farmers of our country started to spray pesticide at an early stage of rice and continue upto flowering for securing their crops. The application of these insecticides can't protect against the real loss of production in our country. Moreover, this chemical insecticide hampers the natural regulation of insect pests in the rice field and enhances the production cost.

At the early growth stage of rice, neutral insects are the food source of the predators due to the lack of insect pests ( $\mathrm{Yu}$ et al., 1999). The number of Chironomid midges can be up to 4.5 million per hectare in the paddy fields, and $80 \%$ of them exist in the early growth period of rice. In this period, Chironomid midges provide plenty of food sources for predators. In the later period of rice, the number of Chironomid midges is decreased, and the predators can feed on insect pests (Wu et al., 1994; Li et al., 2010). In the early rice paddy field with low application of insecticides, plenty of saprophytes can also be an alternative food for the predators.

Application of insecticides at the early period of rice will kill natural enemies and neutral insects, and induce the occurrence of insect pests like rice planthoppers and leaf folders in the later period of rice. Predators, parasites, and parasitoids provide a vital role in checking pest build-up in the rice field. To date, 175 predators and 192 parasitoids are identified at the rice field in Bangladesh which provides natural control of pest outbreaks. Here we propose innovative approaches that might help to enhance productivity by $0.50 \%$ in rice. In this approach, firstly farmers are advised not to apply insecticide in the rice field upto $30-40$ days after transplanting. During this tenure, natural pest control agents boost up and regulate the abnormal growth of insect pests in crop fields. However frequent field visits (7-10 days interval) are suggested to detect any infestation at a significant level. This will limit the chance of production loss.

\section{Web GIS based information visualization for pest infestation and management}

To reduce the loss due to insect pest infestation, careful pest management is crucial. In order to ensure the information is delivered to all farmers, it is proposed to visualize the information via the web geographical information system. The map view is important to help distinguish one place from another and then to make an emergence action to prevent the separation of infestation to the nearest paddy plant. The web geographical information system for pest infestation areas is produced by using ArcGIS online. We will install ArcGIS online in BRRI which produces web geographical information system for pest infestation area. It will visualize the information and deliver to all farmers and other stakeholders who are directly and indirectly involved in rice production in Bangladesh. Figure 6 shows flow diagram web GIS system. The map view is important to help differentiate one place to another and then to take urgent action to prevent the spread of the pest to the nearest rice plant. After getting information on insect pest infested areas, localized application of chemical insecticide for rapid management must reduce pesticide use in Bangladesh. This system also ensures safe food production and reduce national pesticide consumption. 


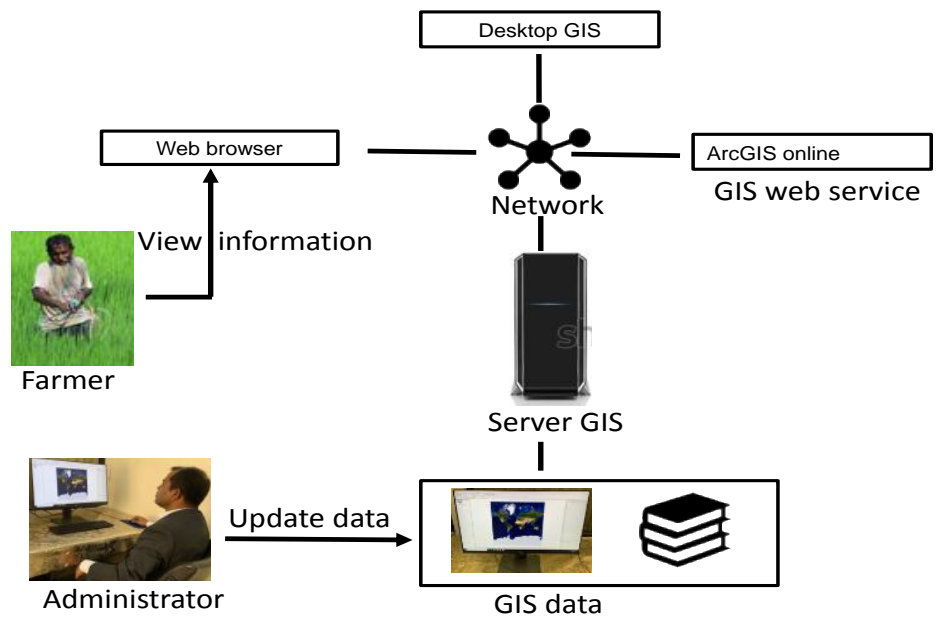

Fig. 6. Flow diagram for web GIS information visualization for insect pest infestation. The model information adopted from Laajis et al., 2016 and has been modified by authors.

\section{Conservation of natural enemies in rice field}

During the last decade, witnessed crop losses caused by pests especially brown planthoppers at an unprecedented scale (Heong et al., 2015). Resistant varieties and formerly effective insecticides are failing because of adaptation in pest populations, making these insects ever harder to control and threatening food security. A viable new, ecologically-based approach that will put rice production on a more sustainable and profitable footing. Our previous studies showing that crop-border plantings suppress rice pests, reduce insecticide use, boost yield and increase profit to put national/global rice production on a more profitable and sustainable footing (Gurr et al., 2016; Ali et al.,2019). Selecting flowering plants that are well-suited for growing on the earth banks beside rice crops. These provided refuge and nectar for beneficial insects that in turn attack pests. Carefully-selected flowering crops on the earth banks in the vicinity of rice fields suppress potentially devastating pests of rice crops, thus providing valuable ecosystem service (Fig. 7A). This flower power' approach effectively promotes beneficial insects that check pest build-up. Farmers can grow flowering plants in rice bunds around the field especially during the dry season and stop insecticide application in their field.
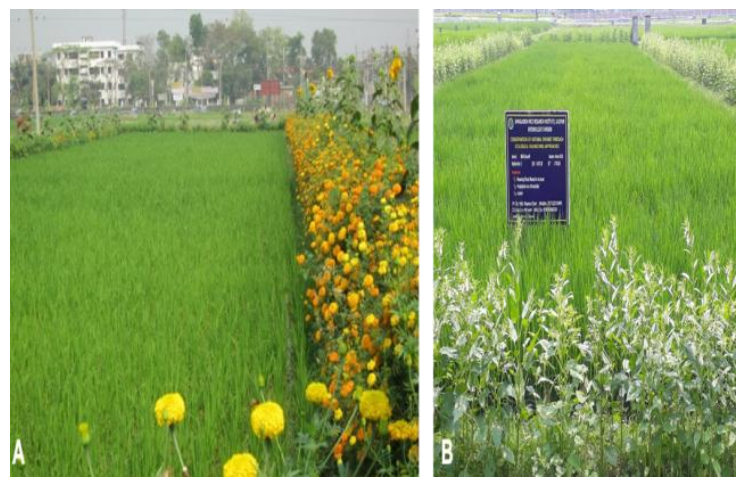

Fig. 7. Flowering plants were grown on the bunds in rice plots to provide resources for biocontrol agents, especially parasites/parasitoids, in rice landscapes. (A) Flowering plants (sunflower, marigold, cosmos) grown on bunds during Boro 2017-18. (B) Sesame plants grown on bunds at T. Aman 2017, BRRI, Gazipur.

Additionally, some border crops can be used as vegetables, or provide fruits or other seeds which also can be harvested to provide a dual income and add to the diverse diets and livelihoods (Fig. 7B). Levels of pest control would be improved compared with conventional practice to the extent that host farmers reduced the numbers of insecticide sprays by more than three-fold (Gurr et al., 
2016; Ali et al., 2019). Significant higher percentage of egg parasitism of $\mathrm{BPH}, \mathrm{WBPH}$, stem borer, and rice hispa was found (Fig. 8). This result indicates that a significant highernumber of parasitoids including Anagras, Trichograma zahiri and Trichgrama chilonis prevails in rice field where nectar rich flowering plants are grown that ultimately reduce insect pest number in the field (Ali et al., 2019). Even better, rice yield improved by $5 \%$ in the flower-bordered rice crops (Gurr et al., 2016). Farmers will be able to harvest these secondary crop borders at the end of the season to diversify diets and as a secondary income that - together with reduced spraying costs and boost rice yield increased economic advantage by 7.5\% (Gurr et al., 2016).

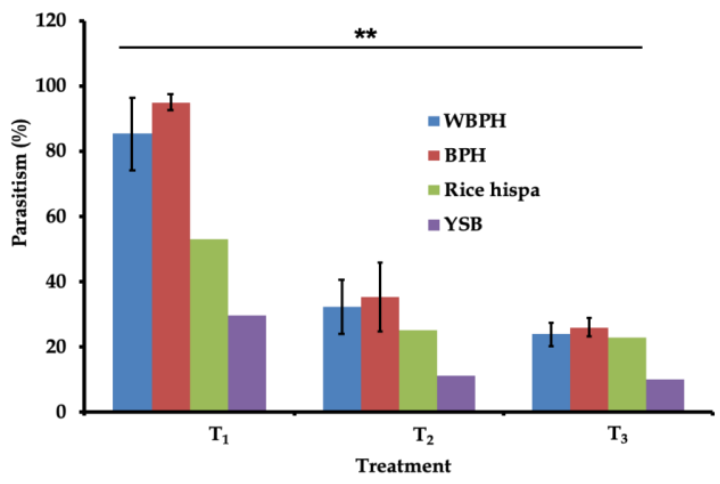

Fig. 8. Percent egg parasitism of brown planthopper $(\mathrm{BPH})$, white backed planthopper (WBPH), yellow stem borer (YSB) and rice hispa egg in different treatments $\left(\mathrm{T}_{1}=\right.$ Flowering plants grown on rice bund, $\mathrm{T}_{2}=$ Prophylactic insecticide use, and $\mathrm{T}_{3}=$ Control (No insecticide and no flowering plants) in Boro season. Error bars indicate standard errors. Data were recorded by egg bait trap method. ** indicates significant at the $1 \%$ level.

Conservation of natural enemies in rice landscape has a sound background for pest management through ecological engineering and has a great opportunity to accept in our society. Ecological engineering has recently emerged as a paradigm for considering pest management approaches that are based on cultural practices and informed by ecological knowledge rather than on high technology approaches such as synthetic pesticides and genetically engineered crops (Gurr et al., 2004). Thus, ecological engineering emerges as a new direction for agricultural pest management (Gurr et al., 2014). Bunds (levees of the terrestrial area surrounding the fields) build an extensive network that connects rice fields. Typically, they have sparse seminatural vegetation that can potentially offer alternative food resources or refugia to natural enemies (Way and Heong, 1994) and likely facilitate the ability of rice arthropods to move through the rice agroecosystem. For example, specific egg parasitoids that cause high mortality of pest planthoppers occur in wild grasses on rice bunds (Yu et al., 1996). Some spider species, which commonly inhabit bund vegetation, are known as early colonizers of newly established rice crops (Sigsgaard, 2000).

Seeding or planting flower strips on these bunds (Fig. 7) enhance parasitoids as well providean important food source for honey bees. Because the later are highly valued in rural communities, it is easier to convince farmers not to spray insecticides, which in turn also leads to less disturbance of the ecological network within and along with rice fields. As an additional benefit, landscapes are perceived as more beautiful. The involvement of farmers in these ecological engineering activities enhances the acceptance and effectiveness of landscape-wide management of biocontrol and other ecosystem services (Westphalet al., 2015).

\section{Insect pest management in rice field by chemical pesticide}

To minimize the pest number in the crop field and keep the loss upto $5 \%$ in an odd year, subsequent quick management option such as chemical pesticide is also required with preventive measures. Besides this, there are many options for controlling pests, and many of these options are tailored to specific pests or problems. Integrated Pest Management (IPM) 
is a pest control approach that uses the least toxic methods first. IPM includes common sense methods based on scientific knowledge of the pest and its habits. Methods often include removing pests' food source, blocking their entry into an area or building, using beneficial organisms, and the judicious use of pesticides. In IPM, pesticides may be used as a last resort, when non-chemical controls have failed, and the pest problem is serious enough to require chemical control. This would be highly recommended when an abnormal situation arises in any crop field. However, before deciding to spray chemical insecticide in the crop field, we must need to consider the damaging level in the field. We can tolerate the yield loss caused by different insect pests at a specific infestation level (called economic threshold level, ETL). When the infestation level (deadheart) exceeds the 10-15\% dead heart caused by yellow stem borer, a significant loss will have occurred, and control measures should be initiated immediately. The insect pest specific recommended chemical insecticides would be sprayed immediately at an abnormal situation (outbreak of pest in the field). In this situation, farmers are also suggested to take advice from pest management experts (list are available on BRRI website; www.brri.gov.bd). These professional experts may offer assistance at different stages of your pest control process.

The negative impacts of agrochemicals application in agriculture and malaria eradication programme have been reported and documented over the years. The major problems associated with agrochemicals are negative impacts against non-target organisms, the resurgence of secondary pest populations, the development of resistant organisms, and the expense. Human health and environmental impacts arise from pesticides due to lack of phyletic specificity, pesticide resistance due to limited sources in the bioactivity of pesticides are the major problems which have been associated with the application of chemical pesticides. Moreover, consumers and the food chain alike are increasingly demanding food products that are residue-low or residue-free and produced in more sustainable ways.

Table 6. Management interventions in Bangladesh for achieving the target (rice yield loss reduction) by 2050.

\begin{tabular}{|c|c|c|c|c|}
\hline Intervention & 2020 & 2030 & 2040 & 2050 \\
\hline Early warning system & Nil & Start limited area & $\begin{array}{l}\text { Deliver to } 50 \% \\
\text { farmers }\end{array}$ & $\begin{array}{l}\text { Deliver to } 60 \% \\
\text { farmers }\end{array}$ \\
\hline $\begin{array}{l}\text { Conservation of natural } \\
\text { enemies }\end{array}$ & $\begin{array}{l}\text { Limited in } \\
\text { experimental field }\end{array}$ & $\begin{array}{l}10 \% \text { farmers will } \\
\text { practice }\end{array}$ & $\begin{array}{l}25 \% \text { farmers will } \\
\text { practice }\end{array}$ & $\begin{array}{l}40 \% \text { farmers will } \\
\text { practice }\end{array}$ \\
\hline $\begin{array}{l}\text { Resistant variety } \\
\text { developed using } \\
\text { CRISPR Cas9 }\end{array}$ & Nil & $\begin{array}{l}10 \% \text { farmers will } \\
\text { produce this } \\
\text { variety }\end{array}$ & $\begin{array}{l}20 \% \text { farmers can } \\
\text { produce this variety }\end{array}$ & $\begin{array}{l}40 \% \text { farmers can } \\
\text { produce this variety }\end{array}$ \\
\hline Chemical control & Exist & $\begin{array}{l}\text { Localized } \\
\text { application only in } \\
\text { outbreak field }\end{array}$ & $\begin{array}{l}\text { Localized } \\
\text { application only in } \\
\text { outbreak field }\end{array}$ & $\begin{array}{l}\text { Localized } \\
\text { application only in } \\
\text { outbreak field }\end{array}$ \\
\hline
\end{tabular}


To avoid such dramatic impacts and to get out of this deadend, alternative pest control strategies must be developed to deliberate cost efficiency, low possibility to develop resistance, less negative impact on the environment. To address this problem, several sequential strategies are proposed here that ensure to reduce the losses caused by insect pests in rice and promote safe food production in Bangladesh. Table 6 enlists the all management interventions with a specific target timeline.

\section{Insect resistance breeding and functional mechanism}

Resistant rice cultivars are being sought as an effective integrated pest management tactic for rice production. A major objective of rice breeding programs is to incorporate insect resistance into modern cultivars (Zhang 2007). Insect resistance in plants involves a gene or suite of genes that produce a product or products that inactivate or otherwise disable the target insect. Resistant rice cultivars alter the physiology and behavior of insects, which in turn affects the insects' susceptibility to chemical and biological control mechanisms (Li et al., 2014). Transgenic rice harboring an exogenous Bt gene (encoding an insecticidal toxin produced by Bacillus thuringiensis) has been used to breed insect-resistant rice. The $\mathrm{Bt}$ gene is effective against the stem borer and leaf roller chewing insects, but not against piercing and sucking insects, such as brown planthopper (BPH).

Over the past several decades, great progress has been made in the screening of insect-resistant rice germplasm, identifying resistance genes, and uncovering the molecular mechanisms of host resistance. The use of resistance genes and other efforts to breed "Green Super Rice", a highyielding, good quality, insect resistant ideal rice variety, will increase the profitability of rice production and contribute to a healthy ecological environment. This review addresses research advances underpinning strategies to improve the resistance of rice to insect pests. We need to focus on the genetic and molecular mechanisms of insect resistance and the practical application of gene technologies to rice breeding for improved insect resistance, which represent the development trend of rice insect resistance breeding and also provide a reference for other crops.

Marked progress has been made in recent years to map, clone, elucidate the underlying resistance mechanisms, and leverage insect resistance genes in rice, allowing for a better understanding of the molecular basis of such resistance and facilitating efforts to breed insect-resistant rice varieties. However, many challenges remain in our efforts to achieve reliable insect resistance in rice. As rice resistance to insects in rice coevolved with the insects themselves, insect resistance genes are more frequent in regions of the world where pests are more common. Therefore, efforts to more thoroughly screen rice germplasm resources in these regions will provide the opportunity to identify additional insect resistance germplasm. The 3000 Rice Genome Project has resequenced a core collection of 3000 rice accessions from 89 countries to an average sequencing depth of $14 \times$ (The 3000 Rice Genomes Project 2014). This and other high-throughput sequencing efforts and related SNP data offer an opportunity to leverage genome-wide association studies to detect and exploit insect resistance genes. The findings of such studies offer ways to better analyze allelic variations and distributions in insect resistance genes within the germplasm, enabling studies of their origins and evolution.

Over the past decade, rapid technological advances have been made in the discovery and analysis of plant and insect genomes, transcriptomes, proteomes, and secretomes. These techniques have provided the impetus to identify putative insect effectors, clone insect resistance genes, and reveal the signaling pathways and key components of plant-insect 
resistance signals. However, there is still a major gap in our understanding of insect-plant interactions. No effectors corresponding to the $\mathrm{R}$ gene have yet been identified, although 14 insect resistance genes (encoding LecRK and NLR proteins) have been cloned in rice. Similarly, although three effectors have been identified from Hessian flies, the corresponding $\mathrm{R}$ genes have not been cloned. The roles of hormone signaling and the corresponding regulatory genes involved in insect resistance in rice have been discovered, and a preliminary regulatory network has been constructed (Du et al. 2020). However, the roles of insect resistance genes in this network are still unclear. Furthermore, no substances that are lethal to insects have been identified in rice. Studies aimed at addressing these issues will provide a more thorough understanding of how these resistance proteins recognize and mediate effector-triggered signaling and immunity against insects.

Because multiple insect pests are simultaneously present in the field, the indiscriminate use of insecticides for pest management is more practical, economical, and effective than growing insect-specific resistant rice varieties. Therefore, insect resistance breeding must involve the incorporation of broad-spectrum resistance genes to minimize the investment in crop management, making this technique more suitable for meeting the expected return on investment of rice farmers in the future. Now, MAS has already been used to pyramid multiple insect resistance genes to cultivate durable, broad-spectrum insect resistance rice. The following approaches need to be applied for future insect resistance breeding in Bangladesh.

1. Marker-assisted selection

2. Molecular understanding of insect resistance

3. Identification and mapping insect resistance gene

4. Cloning and characterization of insect resistance genes in rice
5. Resistance associated signal transduction in rice

6. Insect defense related metabolites

7. Plant mediated RNA interference.

\section{Promising advanced tools for insect pest management}

\section{Development of insect-resistant variety by CRISPR Cas9}

Developing resistance variety is the most economic and environment friendly avenue to combat insect pests and reduce loss. In addition modern breeding approaches, new emerging technologies such as CRISPR Cas9 gene editing to convert insect susceptible alleles to insect resistance alleles, as well as altering the levels of specific secondary metabolites in vivo, provide the potential to design crops that can be patched in real time to combat evolving pests. Furthermore, these emerging technologies will be invaluable for uncovering the roles of insect effectors and plant target proteins in the regulation of plant immunity. In rice, the gene CYP71A1 encodes a cytochrome P450 monooxygenase, which exhibits tryptamine 5hydroxylase enzyme activity, catalyzing the conversion of tryptamine to serotonin. In CYP71A1 knockout mutants, prevention of serotonin synthesis increases resistance to rice blast Magnaporthegrisea but increases susceptibility to rice brown spot disease Bipolaris oryzae. Furthermore, Stripped stem borer (SSB) could induce serotonin synthesis in rice plants potential role of serotonin in the regulation of insect resistance. In susceptible wild type rice, planthopper feeding induces biosynthesis of serotonin and salicylic acid (SA), whereas in mutants with an inactivated CYP71A1 gene, no serotonin is produced, SA levels are higher and plants are more insectresistant (Lu et al., 2018). Addition of serotonin to the resistant rice mutant and other $\mathrm{BPH}$ resistant genotypes results in a loss of insect resistance (Lu et al., 2018). Similarly, serotonin supplementation in an artificial diet enhances the performance of both insects. Furthermore, 
SA depresses CYP71A1 expression and thus serotonin production, and serotonin represses expression of SA biosynthesis genes and thus SA synthesis, suggesting a mutual negative feedback mechanism regulating the differential accumulation of these two hormones. Brown planthopper, Nilaparvata lugens (Homoptera: Delphacidae) and yellow stem borer, Scirpophaga incertulas (Lepidptera: Pyralidae) are major insect pests in Bangladesh cause serious yield losses in rice. We will develop these insect pests resistant rice varieties using CRISPR Cas9 (clustered regularly interspaced short palindromic repeats) system with a similar yield to current mega cultivars by inhibiting serotonin synthesis in rice plants.

\section{Use of drone for insect pest management in rice field}

Most of the farmers of our country are illiterate and ignore the vigilance of crop fields regularly. Therefore, they only identify the field when losses have already been done. Early detection of insect pest infestation in the field will limit the production loss. So, the effort to early detection of insect pest infestation will reduce the production loss in Bangladesh. We will propose to monitor rice fields using a specialized drone (drone with insect monitoring tool) that will help to early detection of insect pest infestation. We will fly the drone from each Upazila Agricultural Office to a specific rice field within the Upazila peripheryat 7-10 days intervals to monitor and making the decision to spray or not to control insect pests. We have a light trap to catch insect pests at every night in the rice field. Our strategy to attached this light trap with the drone and fly them to the rice field at 15 days intervals (it may be 10-15 days). When the drone will reach a target rice field, light trap will be started and attract to catch insects. After 2- 3 hours, the drone will be withdrawn from the rice field and counted the caught insects. The recorded insect pest will be analyzed and used to decideto control them in the field. If the analysis results indicate that pest control measures need to be initiated and farmers could be advised to apply control. This process will identify earlier any infestation that can cause serious losses later.

\section{Application of gene drive technique for rice insect pest management}

Gene drives will replace all conventional insect population control strategies, such as the Sterile Insect Technique, which is used to control fruit flies in Australia and mosquitos around the world. Because gene drive strategies will not require that insects are continually bred and released from factory scale insectaries in an attempt to inundate pest populations. The synthetic gene drives spread themselves, potentially doubling every generation, so that only relatively small numbers of gene-drive bearing insects would need to be released to inoculate a pest population. By 2030, we aim to develop a male population of a brown planthopper using the gene drive technique which reproduces the only son when mates with females in nature. If successful, this research will pave the way pest management approach without damaging diversity and the environment ultimately leading to a next generation crop protection approach.

The overall goal of this method is to apply for recent advances in gene editing (CRISPR Cas9) to produce a suitable treatment to suppress insect pest populations from rice crops. The central hypothesis of the proposed research is that 'gene drive' bearing male insects will be released so that all mated females will only produce males, thus reducing the population of females, and thereby reduce the fecundity of the entire brown planthopper (hereafter BPH, Nilaparvata lugens, the most rice damaging insect pest) population. In this method, we will develop a male population of a $\mathrm{BPH}$ using a gene drive technique, which will result in all offspring post mating being male, no females. 
In turn, implementing this "BPH-Allmale", gene drive treatment could significantly reduce use of pesticides, while increasing biodiversity in the ecosystem, and enabling a larger benefit from beneficial arthropods (predators, parasitoids, and pollinators). Rice produced without pesticide will grantee export quality and consumer satisfaction.

In $\mathrm{BPH}$, two genes including Nlds $x$ and Nltra2 are found to play important roles during the sex determination in the $\mathrm{BPH}$; moreover, the sex-specific splicing of Nldsx is common, with Dmdsx exhibiting different repeat nucleotide sequences on the femalespecific exon (Zhuo et al., 2018; Zhuo et al., 2017). The NIFmd (female determinant factor) is involved in the sex determination cascade of BPH. Knock out of NIFmd gene from $\mathrm{BPH}$ produces only male population (Zhou et al., 2019). This result indicates that inhibition of NIFmd gene in BPH reproduces only male population when these male mate with other female available in field, their next generation will be all male also.Moreover, NlFmd homologs play roles during the sex determination of the whitebacked planthopper (Sogotella furcifera), and the small brown planthopper (Laodelphax striatellus) (Zhuo et al., 2019).

We will use gene drive to produce $\mathrm{BPH}$ male using CRISPR Cas9 genome editing system. Figure 9 shows the design (mechanism) of gene drive approach that will be adopted in this project. The RNA guide will incorporate sequences to target a NIFmd gene that is useful to clearly identify if the system is working. Gene may be the sex-specific transcript of NIFmd (NIFmd-F) encodes an arginine/serine, and proline-rich protein that is essential for female development (Zhuo et al., 2019). This system may have the following components: (1) Cas9 endonuclease required for DNA cleavage, (2) sgRNA containing the 20 base target sequence for the sex-specific transcript of NIFmd (NIFmd-F) that is essential for female development as well as the region that forms a complex with the Cas9 nuclease, and (3) the 'cargo' gene controlling the desired trait pass generation to generation. Free online tools can be used to search the coding region to identify an appropriate 20bp target sequence that is downstream from a protospacer adjacent motif(PAM) sequence that will be cleaved by the Cas9 nuclease.

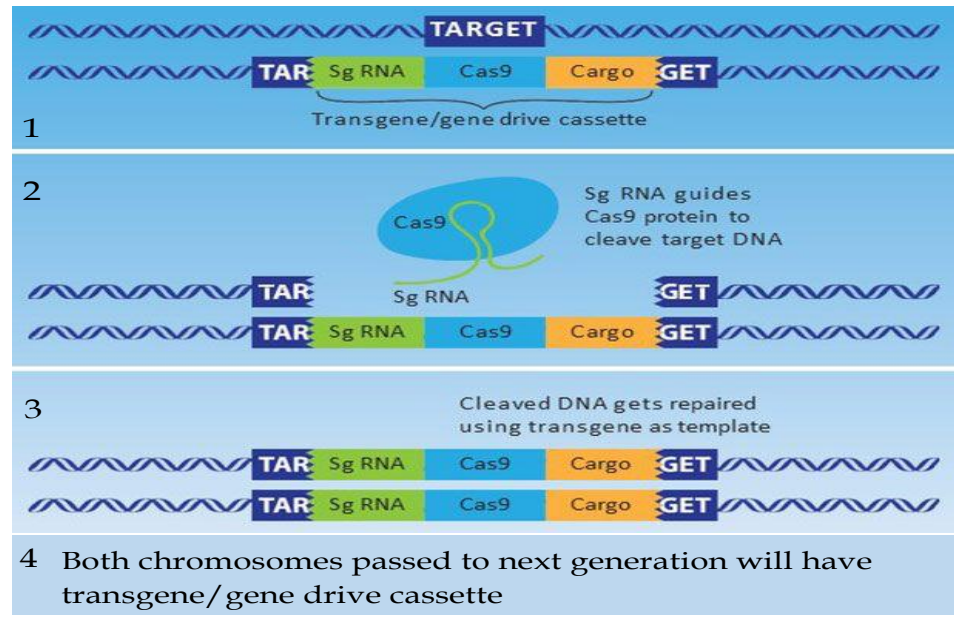

Fig. 9. A synthetic CRISPR Cas9 gene drive. Sg RNA is the guide RNA, Cas9 is an endonuclease which cuts the DNA and cargo is the desired genetic material added. When all three elements are present in a gene drive cassette this ensures that each chromosome will have the desired cargo and will be inherited by the next generation thereby spreading. The figure is adapted fromwww.science.org.au. 


\section{Gene drive mechanisms}

Recent advances in gene editing tools allow organisms to be edited much more efficiently and more accurately than previously possible. Scientists can now harness gene drive mechanisms which were previously merely theoretical to control or alter natural populations. While not a gene drive tool in its own right, clustered regularly interspaced short palindromic repeats of base sequences (CRISPR), can be used as part of a system to produce a synthetic gene drive.

When CRISPR is paired with a guide RNA and with specific proteins, such as Cas9 (CRISPR associated protein 9) that cuts DNA, it can be used to efficiently edit genetic material. In natural prokaryotic systems, CRISPR/Cas9 is produced by host bacteria to remove viral DNA by targeting repeats associated with viral insertions, as a kind of immune system to combat infections. For gene editing purposes, the Cas9 protein and guide RNA are injected into the cell to cut the DNA at a sequence complementary to the RNA guide. For synthetic gene drives, the target organism is transformed with a construct that includes the gene for the Cas9 protein, a guide RNA that is complementary to the sequence at the insertion site, and the 'cargo' gene controlling the desired trait (Fig. 9). The guide RNA directs Cas9 to produce a double stranded cut in the DNA at the target site in the other chromosome. This triggers the cell's repair mechanism, which copies the entire construct (Fig. 9). If germ cells are targeted, the new sequence can then be passed on to offspring ensuring the editing changes can occur in each generation. A CRISPR-based gene editing technique are used in all four synthetic gene drive proof-of-concept studies in 2015 and applied to be generated laboratory-based gene drives in yeast Saccharomyces cerevisiae (DiCarlo et al., 2015), fruit fly Drosophila melanogaster (Gantz and Bier, 2015) and two mosquito species Anopheles stephensi (Gantz, 2015) and Anopheles gambiae (Hammond et al., 2018).

\section{Implementation strategy}

- Training of farmers and sub-assistant agricultural officers (SAAO)would be conducted to motivate them to stop insecticide application at the early establishment stage of rice.

- Early warning systems of insect pest infestation in the rice field would be developed and delivered to farmers at local scales. In addition, the web geographical map for pest infestation area is produced by using ArcGIS online and information is delivered to all farmers via the web geographical information system.

- Motivate farmers to conserve natural enemies in the rice field through an ecological engineering approach. Broadcasting via national media like $\mathrm{TV} /$ radio or newspapers can motivate farmers to conserve natural enemies.

- Develop and deliver brown planthopper resistance rice varieties (developed through CRISPR Cas9 approach) to farmers.

- Gene drive brown planthopper (BPH) population will be developed using CRISPR Cas9 and release into the outbreak area. Released gene drive male BPH mates with female in the field and subsequently replace all females.

- Chemical insecticides are also suggested to apply as the last option when an abnormal outbreak of pest occurs.

\section{CONCLUSION}

Most of the approaches described here ensure safe food production in Bangladesh. Rice fields need to be monitored at 7-10 days intervals for checking levels of pest infestation. Field 
monitoring helps farmers best control their rice pests. Refraining farmers from applying insecticides to rice fields before 30-40 days after transplant (DAT) enhances natural enemy activity to check the build-up of pest populations. Practicing the need-based application of insecticide also significantly reduces the total pesticide load in rice fields. In addition, recent advent genetic techniques such as gene drive and developed resistant variety by applying CRISPR Cas9 need to be adopted to ensure safe food production in Bangladesh. Based on the discussion, it is concluded that currently, farmers should avoid prophylactic measures, and rather farmers monitor their crop fields at 7-10 days intervals up to the flowering stage and prepare to adopt more advanced techniques such as gene drive. All of these will reduce pesticide use in agricultural landscapes and improve environmental quality.

\section{RECOMMENDATION}

- Developing an early warning system on insect pest infestation and inform farmers.

- Developing digital platform for reaching early warning signals and smart pest management systems to farmers.

- Making research investments and policy changes that emphasize the development of pesticides and application technologies that posereduced health risks and are compatible with ecologically based pest management.

- Promoting scientific and social initiatives to develop and use alternatives to pesticides more competitive in a wide variety of managed and natural ecosystems.

- Increasing the ability and motivation of agricultural workers to lessen their exposure to potentially harmful chemicals and refines worker-protection regulations and enforce compliance with them.
- Reducing adverse off-target effects by judicious choice of chemical agents.

- Implementing precision insecticide application technologies.

- Exploring more recent advent genetic tool for effective sustainable management of rice insect pests in Bangladesh.

\section{ACKNOWLEDGEMENTS}

The authors wish to thank anonymous reviewers for their suggestions, which significantly improved this article.

\section{AUTHORS' CONTRIBUTION}

MPA, MUS, and MSK generated idea; MUS and MSK coordinated the research; MPA developed methodology; MPA, BN and MTK provided scientific insights; MPA gathered data, carried out analysis and synthesis; MPA did the writings for all versions of the manuscript; BN, MTK, MUS and MSK performed critical review and editing; All authors read and approved the final manuscript.

\section{DECLARATION OF INTERESTS}

A version of the paper was published in a book "Doubling Rice Productivity in Bangladesh" in 2020 by the Bangladesh Rice Research Institute (BRRI), Gazipur 1701, Bangladesh to commemorate BRRI's 50th anniversary. The Bangladesh Rice Journal has prior knowledge of the book publication and does not see any conflict of interest.

\section{REFERENCES}

Alam, M Z. 1961.Insect Pests of Rice in East Pakistan and theirControl. EastPakistan Department of Agriculture, Dacca, $94 \mathrm{p}$.

Alam, M Z. 1967. Insect pests of rice in East Pakistan. In: Major Insect Pests of the Rice Plant,R Peshin and A K Dhawan (Eds.). Johns Hopkins Press, Baltimore, MD, USA, 643-655.

Ali, M P, M N Bari, S S Haque, M M M Kabir and J Willer. 2017. Rice Production without Insecticide in 
Smallholder Farmer's Field. Frontiers in Environmental Science, 5:16. DOI: 10.3389/fenvs.2017.00016.

Ali, M P, M N Bari, S S Haque, F Nowrin, S Afrin and D Landis. 2019. Establishing next-generation pest control services in rice fields: ecoagriculture. Scientific Report, 9: 10180. DOI: 10.1038/s41598-019-46688-6.

BBRI (Bangladesh Rice Research Institute). 1985a. Annual Report for 1981. BRRI, Gazipur-1701.

BRRI (Bangladesh Rice Research Institute). 1985b. Annual Report for 1982. BRRI, Gazipur-1701.

Bari, M N, N Ahmed, S S Haque, M F Rabbi and M K Iftekharuddaula. 2015. Validation of integrated pest management practices for rice insects in North-west region of Bangladesh. Bangladesh Rice Journal, 19: 1731.

Bari, M N, M F Rabbi, M Hasan and M P Ali. 2012. Assessment of Yield Losses of Some Modern Rice Varieties due to Rice hispa infestation in different rice seasons of Bangladesh. Bangladesh Journal of Entomology, 22 (1): 47-59.

BBS (Bangladesh Bureau of Statistics). 2011. Statistical Yearbook Bangladesh. Ministry of Planning, Government of the People's Republic of Bangladesh, Sher-E-Bangla Nagar, Bangladesh.

BBS (Bangladesh Bureau of Statistics).2015. Labour survey for Bangladesh 2013. Ministry of Planning, Government of the People's Republic of Bangladesh, Sher-E-Bangla Nagar, Bangladesh.

BCPA (Bangladesh Crop Protection Association). 2013: List of Registered Agricultural, Bio \& Public Health Pesticides in Bangladesh. 142p. Retrieve from http:/ / www.bcpabd.com

Bautista, R C, E A Heinrichs and R S Rejesus. 1984. Economic Injury Levels for the Rice Leaffolder Cnaphalocrocis medinalis (Lepidoptera: Pyralidae): Insect Infestation and Artificial Leaf Removal. Environmental Entomology, 13 (2): 439-443.

Catling, H D, S Alam and S A Mia. 1978. Assessing losses in rice due to insect pests and disease in Bangladesh. Experimental agriculture, 14: 277-284.

Conway, G R and J N Pretty. 1991.Unwelcome Harvest: Agriculture and Pollution. Earthscan, London, 645.

DiCarlo, J E, A Chavez, S L Dietz, K M Esvelt and G M Church. 2015. Safeguarding CRISPR-Cas9 gene drives in yeast. Nature Biotechnology, 33 (12): 1250-1255.

Du B, Chen R, Guo J and He G. 2020, Current understanding of the genomic, genetic, and molecular control of insect resistance in rice. Molecular Breeding, 40: 24 .

20 Ali et al.
Gantz, V M and E Bier. 2015.The mutagenic chain reaction: a method for converting heterozygous to homozygous mutations.Science, 348 (6233): 442-444.

Graf, B, R Lamb, K L Heong and L T Fabellar. 1992. A simulation model for the population dynamics of the rice leaffolders (Lepidoptera: Pyralidae) and their interactions with rice. Journal of Applied Ecology, 29: 558-570.

Gurr, G M Z Lu, Z Zheng and H Xu.2016. Multi-country evidence that crop diversification promotes ecological intensification of agriculture. Nature Plants, 2(3): 16014.

Gurr, G M, S D Wratten and M A Altieri. 2004. Ecological Engineering: Advances in Habitat Manipulation for Arthropods. CSIRO Publishing, pp: 244.

Gurr, G M, S D Wratten and M A Altieri. 2014. Ecological engineering: a new direction for agricultural pest management. AFBM Journal, 1(1): 28-35.

Halteren, P V. 1979. The insect pest complex and related problem of the low land rice cultivation in South Sulawesi, Indonesia. PhD thesis. Department of Entomology, Agricultural University,Mededelingen Landbouwhoge school Wageningen 79-1, Wageningen, The Netherlands.

Hammond, A M, A Hammond, K Kyrou and M Gribble. 2018. Improved CRISPR-based suppression gene drives mitigate resistance and impose a large reproductive load on laboratory-contained mosquito populations. Bio Rxiv, DOI: https://doi.org/10.1101/360339.

Haque, S. 2014. Insecticide resistance in Brown planthopper Nilaparvata lugens (Stål) (Homoptera: Delphacidae) in Bangladesh. PhD thesis. Jahangir Nagar University, Savar, Dhaka.

Heong, K L, L Wong and J H D Reyes. 2015. Addressing planthopper threats to Asian rice farming and food security: fixing insecticide misuse in Rice Planthoppers. ADB Sustainable

Development Working Paper Series.DOI: adb.org/sites/default/files/ /30362.

Islam, Z, N Ahmed and M Haq. 2003. Some ecological aspect of rice bug in Bangladesh. Bangladesh Journal of Entomology, 13 (1): 85-96.

Islam, Z and D Catling. 2012. Rice pest of Bangladesh. Their ecology and management. The university press limited, Dhaka, 451.

Johnson, D. 2013.UK insect pest early warning system benefits producers. Available inhttps:/ / news.ca.uky.edu/article/uk-insect-pestearly-warning-system-be nefits-producers. 
Kabir, M S, M U Salam, A Chowdhury, N M F Rahman, K M Iftekharuddaula, M S Rahman, M H Rashid, S S Dipti, A Islam, M A Latif, A K M S Islam, M M Hossain, B Nessa, T H Ansari, M A Ali and J K Biswas. 2015. Rice Vision for Bangladesh: 2050 and Beyond. Bangladesh Rice Journal, 19 (2): 1-18.

Kabir, M S, M U Salam, A K M S Islam, M A R Sarkar, M A A Mamun, M C Rahman, B Nessa, M J Kabir, H B Shozib, M B Hossain, A Chowdhury, M Nasim, K M Iftekharuddaula, M S Hossain, M K A Bhuiyan, B Karmakar, M S Rahman, M M Haque, M T Khatun, M P Ali, S M H A Rabbi, P L Biswas, E S M H Rashid, and N M F Rahman. 2020. Doubling rice productivity in Bangladesh: A way to achieving SDG2 and moving forward. Bangladesh Rice Journal, 24 (2): 1-47.

Kalode, M B, A N M Karim, S Pongprasad and E A Heinrichs. 1986. Varietal improvement and resistance to insect pests. In:Progress in rainfed lowland rice. IRRI, Manila, Philppines, 241.

Karim, A N M R. 1989. Some recent progress in insect pest management research and problem in rainfed rice. In:Proceedings of a workshop on experiences with modern rice cultivation in Bangladesh. Bangladesh Rice Research Institute, Gazipur-1701, 134-144.

Adidah, L A, H M Nasir and N Ismail. 2016. Web GISBased Information Visualization for Pest Infection: A Case Study of Rice Plantation. Asian Journal of Plant Science, 15: 109-114.

Li, Z Y, H Li, F X Yang, Q Lan and F Y Hu. 2010.Occurrence and population dynamics of chironomid midges in early rice field. Chinese Journal of Rice Science, 24 (6): 630-634.

Li J, K Shang, J Liu, T Jiang, D Hu, H Hua. 2014. Multigenerational effects of rice harboring Bph15 on brown planthopper, Nilaparvata lugens. Pest Management Science, 70: 310-337.

$\mathrm{Lu}, \mathrm{H}, \mathrm{T}$ Luo and $\mathrm{H} \mathrm{Fu}$. 2018. Resistance of rice to insect pests mediated by suppression of serotonin biosynthesis. Nature Plants, 4:338-344.

Lu, Z X, Y J Yang, P Y Yang and Z H Zhao. 2012.China'sGreen Plant Protection' initiative: Coordinated promotion of biodiversity-related technologies. In: Biodiversity and Insect Pests: Key Issues for Sustainable Management, GM Gurr, SD Wratten, WE Suyder and DMY Read (Eds.). John Wiley and Sons, 230-240.

Majumder, S. 2013. The Economics of Early Response and Resilience:Bangladesh Country Study. Available in https://www.gov.uk/government/uploads/sy stem/uploads/attachment_data/file/228494/TEERR _Bangladesh_Background_Report.pdf
Mondal, M H. 2010. Crop agriculture of Bangladesh: Challenges and opportunities. Bangladesh Journal of Agriltural Research, 35 (2): 235-245.

Muralidharan, K and I C Pasalu. 2006. Assessments of crop losses in rice ecosystems due to stem borer damage (Lepidoptera: Pyralidae). Crop Protection, 25: 409-417.

Pathak, M D and Z R Khan. 1994. Insect pest of rice. International Rice Research Institute (IRRI), Manila, Philippines.

Petrella, V, S Aceto, V Colonna, G Saccone, R Sanges and N Polanska. 2019. Identification of sex determination genes and their evolution in Phlebotominae sand flies (Diptera, Nematocera). BMC Genomics, 20: 522.

Rahman, T, M Khalequzzaman and M A Khan. 2004 Assessment of Infestation and Yield Loss by Stem Borers on Variety of Rice. Journal of Asia-Pacific Entomology, 7 (1): 89-95.

Sigsgaard, L. 2000. Early season natural biological control of insect pests in rice by spiders-and some factors in the management of the cropping system that may affect this control. European Arachnology, Aarhus University Press, Aarhus, Denmark, 57-64.

Way, M J and K L Heong. 1994.The role of biodiversity in the dynamics and management of insect pests of tropical irrigated rice-a review. Bulletin of Entomological Research, 84: 567-587.

Westphal, C, S Vidal, F G Horgan, G M Gurr, M Escalada, H V Chien, T Tscharntke, K L Heong and J Settele. 2015. Promoting multiple ecosystem services with flower strips and participatory approaches in rice production landscapes. Basic Applied Ecology, 16: 681689.

Wu, J C, G W Hu, J Tang, Z L Shu, J S Yang, Z N Wan and Z C Ren. 1994. Studies on the regulation effect of neutral insect on the community food web in paddy field. Acta Ecological Sinica, 14 (4): 381-386.

Ye, Z Q. 2013.Accelerate the construction of modern plant protection with vigorously implements of green control.China Plant Protection, 33 (2): 5-9

Yu, X, K L Heong, C Hu and A T Barrion. 1996.Role of non-rice habitats for conserving egg parasitoids of rice planthoppers and leafhoppers.Proceedings of the International Workshop on Pest Management Strategies in Asian Monsoon Agroecosystems.Kyushu National Agricultural Experimental Station, Ministry of Agriculture, Forestry and Fisheries; Kumamoto, Japan, 63-67.

Yu, X P, X S Zheng, X M Chen, Z X Lu and J C Hu. 1999.A study on the relationship between egg parasitoid, Anagrusnipaparvatae and green slender planthopper, Sacch-arosydne procerus, a species of 
insect pest of wild rice, Zizania caduciflora. Acta Entomological Sinica, 42 (4): 387-393.

Zhang J, T Luo, W Wang, T Cao, R Li, Y Lou. 2017. Silencing OsSLR1 enhances the resistance of rice to the brown planthopper, Nilaparvata lugens. Plant Cell Environment, 40: 2147-2159.

Zhuo, J C, Q L Hu, H H Zhang, M Q Zhang, S B Jo and C X Zhang. 2018. Identification and functional analysis of the doublesex gene in the sexual development of a hemimetabolous insect, the brown planthopper. Insect Biochemecistry and Molecular, 102: 31-42.
Zhuo, J C, C Lei, J K Shi, N Xu, W H Xue, M Q Zhang, Z W Ren, H H Zhang and C X Zhang. 2017. Tra-2mediates cross-talk between sex determination and wing polyphenism in female Nilaparvata lugens. Genetics, 207: 1067-1078.

Zhuo, J C, H H Zhang, Y C Xie, H J Li, Q L Hu and C X Zhang. 2019. Identification of a female determinant gene for the sexual determination of a hemipteran insect, the brown planthopper. Bio Rxiv, 775577. DOI: 10.1101/775577. 